\title{
ENVIRONMENTAL CHANGES IN KECSKEMÉT BETWEEN 2009-2018
}

\author{
Edit Hoyk, ${ }^{1,2^{*}}$, Imre Kanalas ${ }^{3}$, Jenő Zsolt Farkas Jenö ${ }^{4}$ \\ 1'Department of Agroecomony and Rural Development, Faculty of Horticulture and Rural Development, John \\ von Neumann University, Hungary \\ ${ }^{2}$ Department of Great Plain, Institute of Regional Studies, Hungary \\ ${ }^{3}$ Kecskemét Urban Development Ltd., Hungary \\ ${ }^{4}$ Department of Great Plain, Institute of Regional Studies, Hungary \\ https://doi.org/10.47833/2020.2.AGR.001
}

\section{Keywords:}

air quality

transport

urban heat island

green infrastructure

water management

Article history:

Received 13 Sept 2019

Revised 10 Marc 2020

Accepted 15 Marc 2020

\begin{abstract}
Kecskemét is the city most exposed to climate change, facing a number of environmental challenges in the Danube-Tisza Interfluve. The most important changes are the deterioration of air quality, the impact of urban heat islands, the problems of green infrastructure and the issue of water management.

In this paper, we briefly present the evolution of environmental factors over the past decade, from 2009 to 2018. Attention is drawn to the increase in traffic load, the deterioration of air quality and the resulting problems. We analyze the evolution, quantity and quality characteristics of the city's green spaces, which are very closely related to water management and underline the need for urban rainwater management.
\end{abstract}

\section{Introduction}

Kecskemét is the largest settlement of the environmentally sensitive (sandy soils with poor water management, sinking groundwater level, aridification) Danube-Tisza Interfluve. Besides this, the city is the most dynamically developing industrial centre of the area, exposed to the effects of climate change. This duality poses an important challenge for urban development professionals.

The city administration is sensitive to environmental and climate issues, but environmental problems have intensified as a result of the economic transformation of the city. The aim of our study is to present the negative processes of the past decade and to highlight the areas that can improve city of Kecskemét as an attractive town between the Danube and Tisza rivers in the future.

\section{Methods}

For the characterization of environmental parameters, our data were collected from various sources. Increase in the number of vehicles is illustrated based on of the data of the Tax Department City of Kecskemét [1], while the road traffic in the vicinity of Kecskemét is shown on the basis of the Hungarian Road Nonprofit Ltd. [2].

The source of air quality indicators ( $\mathrm{NO}_{2}$ and PM10) is www.levegominoseg.hu [4], which provides measurement data for the country's manual and automatic measuring points.

From 2017, HAS CERS Institute for Regional Studies operates four Netatmo NRG01-WW weather stations at four different locations in Kecskemét. The precipitation and temperature values are presented using data from these measurement points in the analysis of urban heat island and green infrastructure.

\footnotetext{
* Corresponding author. Tel.: +36 76501611

E-mail address: hoyk.edit@kvk.uni-neumann.hu
} 


\section{Results}

\subsection{Transportation and air quality}

In Kecskemét, over the past ten years, the industrial capacities built up and more than 8,000 new jobs created. This process indicated higher mobility needs, which has increased the traffic load on the roads of the settlement and brought to light the shortcomings of its road network.

In Kecskemét, the increase in mobility resulted in a significant increase in traffic, which is sensitively demonstrated by the traffic censuses performed in the city (2011 Fömterv, $2016 \mathrm{KTI}$; long-term traffic census data of the Hungarian Road Nonprofit Ltd. [2]). According to the data, between 2011 and 2017, 150 measurement points saw an annual increase of nearly 4\%.

Stopping the unfavourable pocess is vital for Kecskemét. Emissions from road traffic and non-environmentally friendly heating of households have become more frequent, and in the near future various air pollutants (e.g. PM10; $\mathrm{PM} 2.5 ; \mathrm{NO}_{2}, \mathrm{NO} ; \mathrm{SO}_{2} ; \mathrm{O}_{3}$ ) can exceeds limit values frequently.

From the available data, the concentration of highly transport-dependent nitrogen dioxide is illustrated in Figure 1., which shows data for the start year, an intermediate year, and the last two years between 2009 and 2018.

Health limit value for nitrogen dioxide is $85 \mu \mathrm{g} / \mathrm{m}^{3}$ per 24 hours [5]. Figure 1. shows that over 2017-2018 limit values have been exceeded, especially in summer and autumn. Nitrogen dioxide as a pollutant is not only related to transport, but also residential heating. However, summer and autumn limit values are more likely to indicate the origin of traffic. It is worth comparing the percentage increases in monthly averages for 2009 and 2018. The January values are ignored in this case, as there was no values over the limit in this month except for 2017. However spring (April) the average $\mathrm{NO}_{2}$ concentrations were rising by $57 \%$ over ten years. In July 2018, the twoyear growth rate was $169 \%, 197 \%$ in October. In addition to the steep increase in concentration, the monthly (!) average in October 2018 was exceeding the 24-hour limit.

The PM10 concentration data available from 2015 also shows rising concentrations, with several values over the limit $\left(50 \mu \mathrm{g} / \mathrm{m}^{3}\right)$, mainly in January 2016, 2017 and October 2018 (Fig. 2.).

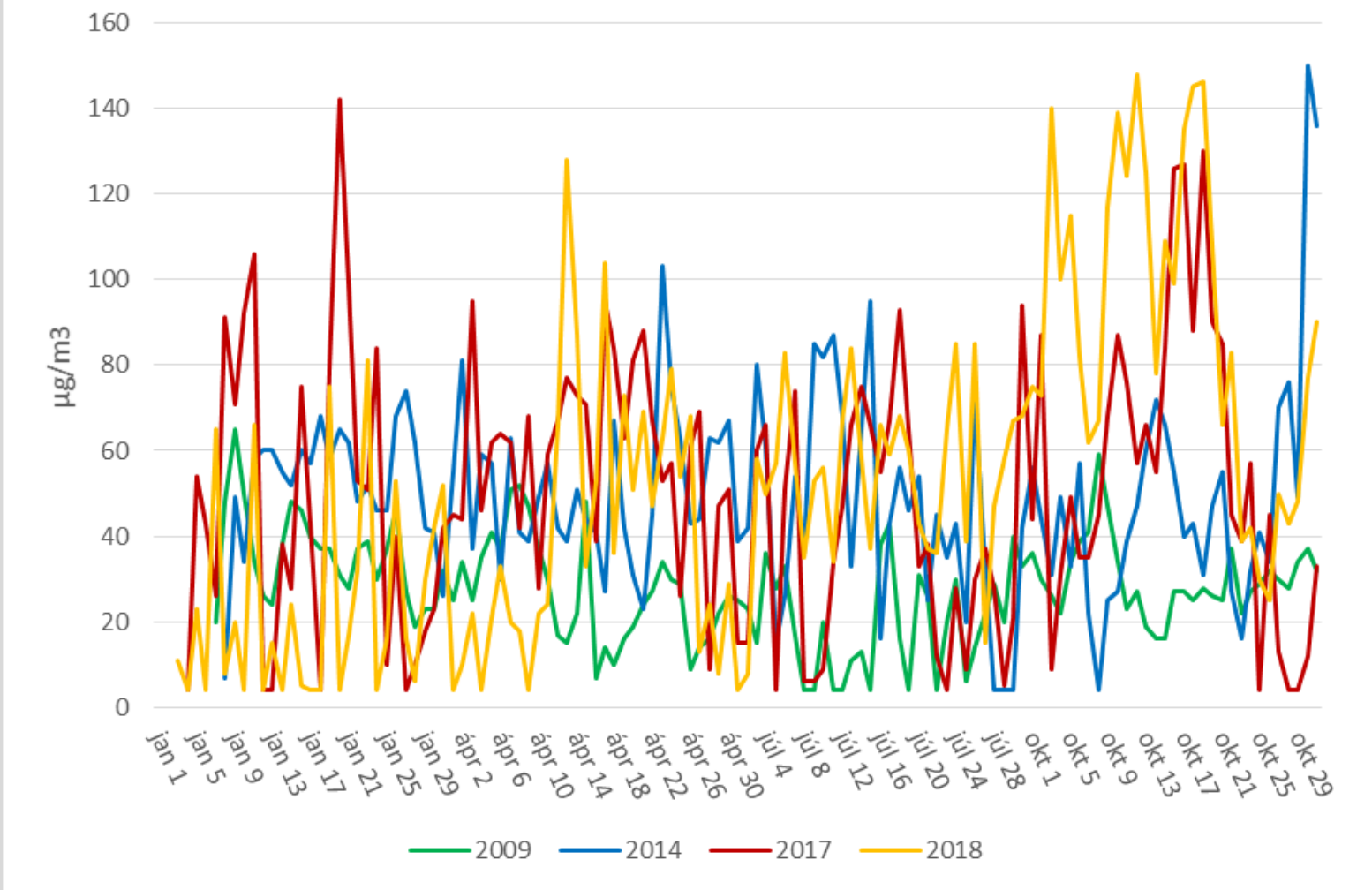

Source: www.levegominoseg.hu

Figure 1. Nitrogen dioxide concentration in Kecskemét 2009-2018 


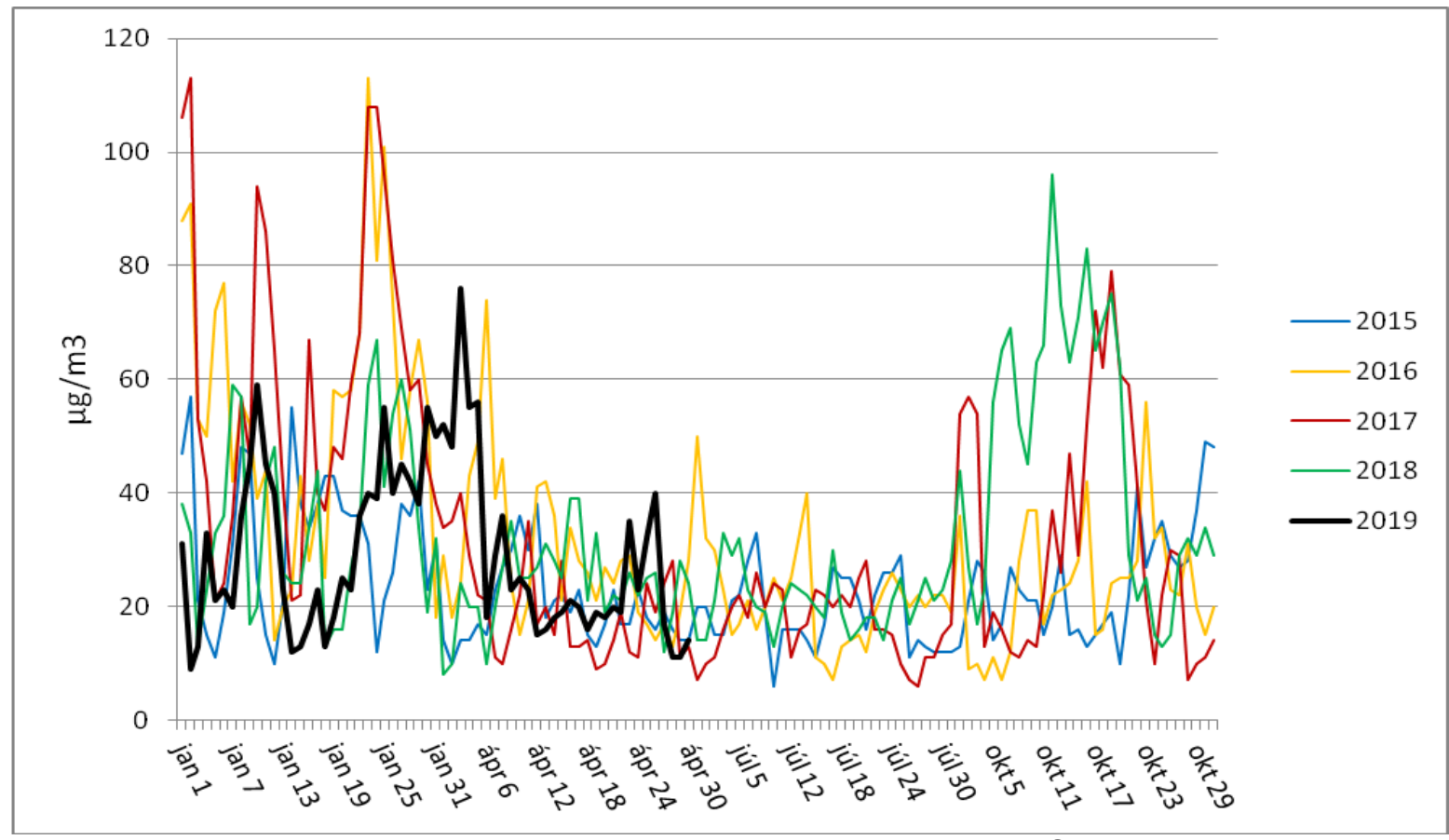

Figure 2. PM10 concentration in Kecskemét 2015-2019

\subsection{Appearance of urban heat island in Kecskemét}

Our August 2018 data (Fig. 3.) show that there was a significant difference in night temperatures between downtown (RKI) and the outskirts (Ladánybenei út), especially in the first half of the month. The difference also reaches $4-5^{\circ} \mathrm{C}$, which means minimum night temperatures of $17-22^{\circ} \mathrm{C}$. This range exceeds the critical night temperature of $20^{\circ} \mathrm{C}$, which is disrupting nightlife for downtown residents.

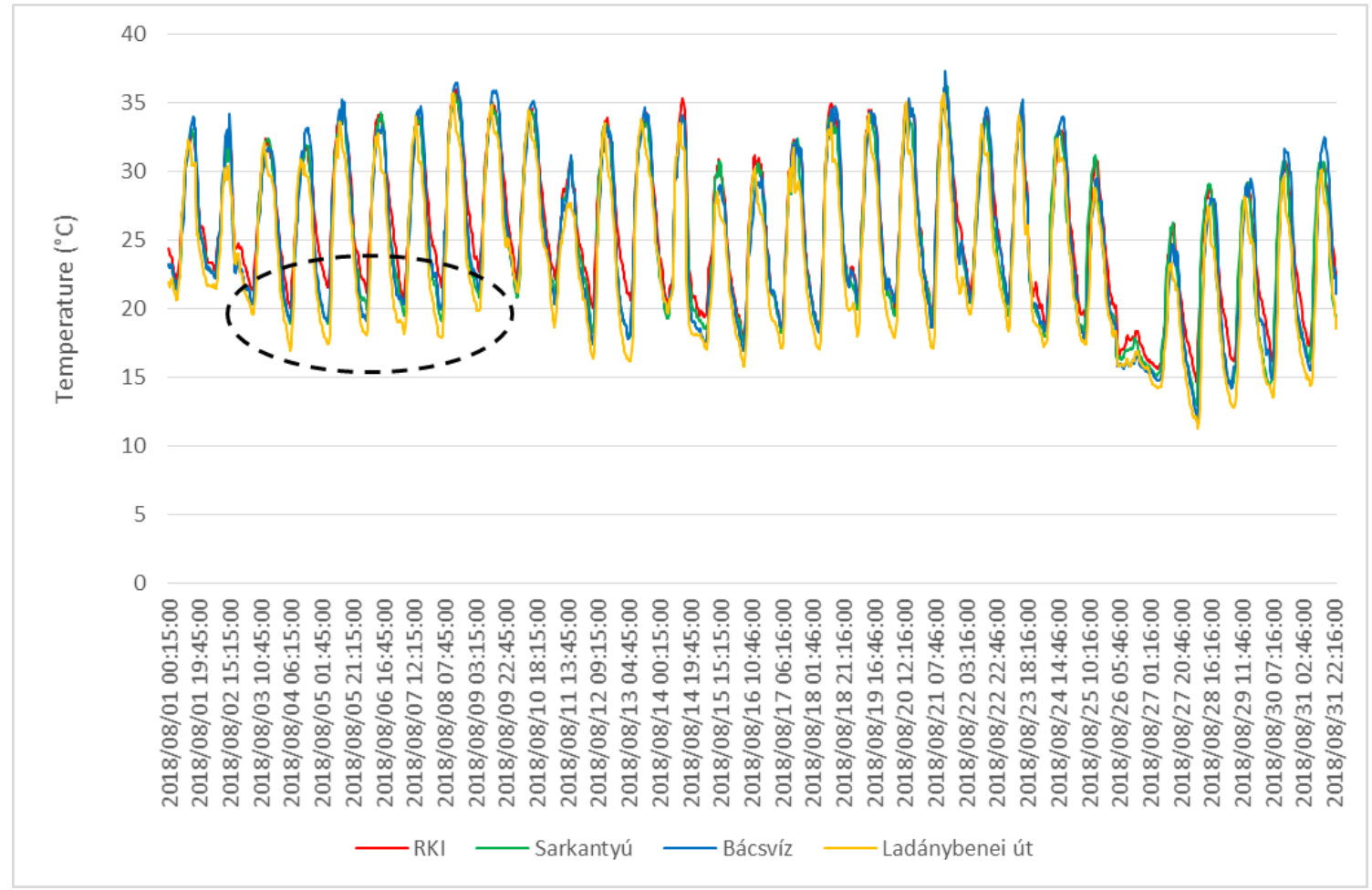

Figure 3. Daily temperatures in Kecskemét (1-31. August 2018) 
Significant differences exist between areas with different surfaces in the city at daytime surface temperatures. The difference is well illustrated by the fact that on the day of August 30 ., 2018 (recording time 10:51 am), the temperature difference between the coldest and the hottest surfaces was $22.78^{\circ} \mathrm{C}$ (of course, the air temperature difference is much smaller as shown by our measurements). The southern industrial area, as well as the giant covered areas of the airport without vegetation, are the warmest parts of the city, but almost all of downtown, as well as densely built-up housing estates (e.g. Széchenyiváros) are among the most heated areas. The temperature-reducing role of green surfaces is evident in larger contiguous areas, such as the Zoltán Benkó Leisure Center (the "green wedge" in the city) or cemeteries.

Smaller green areas (Szabadság Square, Vasútkert, etc.) cannot prevent the overheating of the covered surfaces, however, the vegetation has a temperature-conditioning effect due to the shade effect. Therefore the preservation of the closed canopy is a priority.

\subsection{Green infrastructure}

Another topic with similar importance to the negative consequences of the increase in traffic load is the change in the quantity and quality of urban green areas. The extent of all municipally owned green areas decreased by more than 30\% between 2009 and 2017 [3]. The decline primarily affects the southern industrial area, where Mercedes-Benz and its suppliers' production facilities are located.

The proportion of green areas in Kecskemét (8240 ha green surface/32257 ha administrative area) is $25 \%$, which can be considered as an acceptable level in the region. At the same time, the proportion of green areas in terms of use (public welfare forests, public parks, public gardens, etc.) in the city ( 450 ha of green surface/32257 ha of administrative area) is very low, only $1.5 \%$, which is $24.3 \mathrm{~m}^{2}$ per person. Compared to municipalities with county rights, the value of green surfaces per capita (public parks, public gardens - about $40 \mathrm{ha}$ ) is very low ( $3 \mathrm{~m}^{2} /$ person). This is only about one-fourth to one-fifth of the expected value. This condition made it worse by the $30 \%$ decrease in green surfaces over the last 10 years.

As the green surfaces decrease, the amount of naturally occurring airborne dust increases. At the same time, green areas play acrucial role not only in absorbing pollutants, but also in absorbing $\mathrm{CO}_{2}$ (climate policy expectation), venting the city, increasing evaporation and producing oxygen.

\subsection{Water management and precipitation trends}

In addition to green areas, it is also important to improve water resources in the city and its vicinity. It is necessary to increase surface water bodies and evaporation, which can play a decisive role not only in reducing dust pollution but also pollen concentration. Therefore, it would be essential to develop an urban water management and water treatment strategy. At present, approximately 12 million $\mathrm{m}^{3}$ of water (rainwater and treated wastewater) is drained from the city (via an average annual rainfall of $500-550 \mathrm{~mm}$ ) through the Csukás-ér into the Tisza, at a time when the city needs more surface water bodies and evaporation capacity. The retained rainwater would not only irrigate the city's parks, but also would help to create green areas.

The need for water management is strongly underlined by the extreme extent of rainfall, which is perceptible almost daily in Kecskemét. To justify this, it is sufficient to refer to the MayJune 2019 data on the basis of our four meteorological stations in the city (Fig. 4.). 


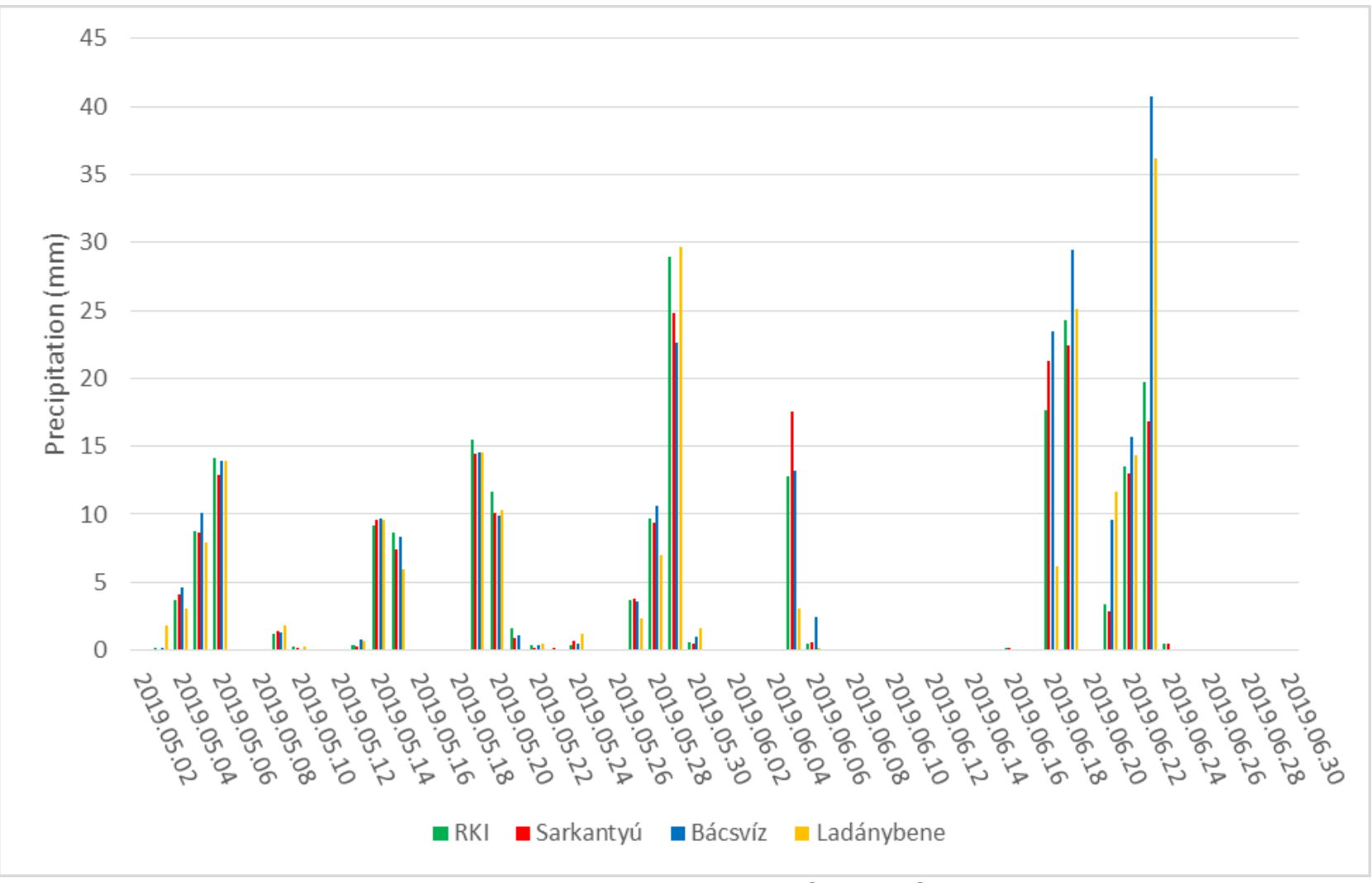

Figure 4. Precipitation in Kecskemét (May 1. - June 30. 2019)

\section{Conclusions}

The environmental sensitivity of Kecskemét requires a great deal of attention from the point of view of urban planning and urban development. In addition to the sensitivity, the city must also comply with EU regulations and obligations stemming from voluntary commitments (e.g. a $40 \%$ reduction in $\mathrm{CO}_{2}$ emissions by 2030). This can only be achieved if serious steps are taken in the topic of environmental protection, of which a significant part is the environmentally consciousness urban development.

This requires both the public and decision-makers to recognize the seriousness of the problems and to be willing to act together to achieve the goals. For this, strong thinking transformation is needed, which is probably the most difficult thing among the tasks.

\section{Acknowledgement}

Thank you for the support of EFOP-3.6.1-16-2016-00006 „Developing and expanding research potential at John von Neumann University" project. This project is supported by the Hungarian State and the European Union, co-financed by the European Social Fund, under the Széchenyi 2020 program.

\section{References}

[1] Kecskemét Megyei Jogú Város Polgármesteri Hivatal Adó Osztály adatai a regisztrált gépjárművek számáról 20082018

[2] Magyar Közút Nonprofit Zrt.: Az országos közutak keresztmetszeti forgalma 2009-2017

[3] www.ksh.hu

[4] http://levegominoseg.hu/automata-merohalozat

[5] http://www.levegominoseg.hu/hatarertek?AspxAutoDetectCookieSupport=1 